\title{
Evaluation of in vitro cytotoxic activity of different solvent extracts of Clerodendrum thomsoniae Balf.f and its active fractions on different cancer cell lines
}

\author{
V. K. Muhammed Ashraf ${ }^{1 *}$ (D, V. K. Kalaichelvan ${ }^{1}$, V. V. Venkatachalam ${ }^{1}$ and R. Ragunathan ${ }^{2}$
}

\begin{abstract}
Background: Clerodendrum is a genus of about 500 species belongs to the family Lamiaceae. Many species of this genus have been proved for the treatment of various diseases. This study was aimed to evaluate the cytotoxic effect of different solvents and their most active fractions of Clerodendrum thomsoniae Balf.f. in different human cancer cell lines. Aerial parts of the plant were subjected to Soxhlet extraction. Phytochemical analysis was done by using standard tests. In vitro anti-cancer activity on MCF-7, Hep-G2, A549, HT-29, MOLT-4, Hela, and Vero cell lines were evaluated by MTT assay.

Results: Phytochemical analysis confirmed the presence of most of the phytoconstituents in ethyl acetate extracts and the same extracts were found to be more cytotoxic activity to cancer cell lines MCF-7,Hep-G2,A549,HT-29, MOLT-4, and Hela with $I_{50}$ values $29.43 \pm 1.44 \mu \mathrm{g} / \mathrm{ml}, 43.22 \pm 1.02 \mu \mathrm{g} / \mathrm{ml}, 56.93 \pm 1.41 \mu \mathrm{g} / \mathrm{ml}, 60.68 \pm 1.05 \mu \mathrm{g} / \mathrm{ml}$, $69.83 \pm 1.33 \mu \mathrm{g} / \mathrm{ml}$, and $40.02 \pm 1.14 \mu \mathrm{g} / \mathrm{ml}$ respectively, while it had no cytotoxic effect on normal Vero cells $\mid \mathrm{C}_{50}=$ $367.5 \pm 1.03 \mu \mathrm{g} / \mathrm{ml}$. Ethyl acetate extracts were selected for the fractionation and MCF-7 cell line was used repeat MTT assay and found that fraction F5 was the most active fraction with $\mathrm{IC}_{50} 17.33 \pm 0.54 \mathrm{\mu g} / \mathrm{ml}$.

Conclusion: These findings have proved that Clerodendrum thomsoniae Balf.f. have significant cytotoxicity especially for breast cancer cell lines. Further studies are required for the isolation of constituents and to explore the mechanism of action.
\end{abstract}

Keywords: Clerodendrum thomsoniae Balf.f, Anti-cancer, Cell lines, Fractions, MTT assay

\section{Background}

Cancer is considered as one of the life-threatening ailments, which include abnormal cell growth with the capacity to continuously multiply and invade from one tissue to the other in the body [1]. The cancer had continuously been the most serious disease in humans around the world due to its high morbidity and mortality [2]. Breast cancer is a significant global health issue and one of the foremost causes of death in females [3].

\footnotetext{
* Correspondence: ashrafvkclt@gmail.com

1 Department of Pharmacy, Annamalai University, Chidambaram, Tamil Nadu, India

Full list of author information is available at the end of the article
}

The World Health Organization (WHO) expects about 15 million new cases of cancer by 2020 [4]. Chemotherapy, radiation therapy, hormonal therapy, and surgery are the common treatments for all kinds of cancer, and due to resistance and adverse or toxic side effects of these treatments, it has become necessary to hunt for an alternative anti-cancer treatment [5]. Natural products preserve vast pharmacological significance and have been considered as a key source of potential chemotherapeutic treatments [6]. Natural products obtained from plants are well-accepted sources and also many drugs are presently used from plant basis for the treatment of numerous human ailments including cancer. 
Over the past few decades, there has been a certain interest in the role of medicinal plant extracts in cancer prevention. Plants are rich sources of chemically diverse compounds, several with beneficial properties to human health. Consequently, about $50 \%$ of the anti-cancer therapeutic agents identified are derived from plants [7]. Several plant-based molecules that consist of vinblastine, vincristine, taxol, and camptothecin derivatives are used clinically to treat various types of cancers [8]. Various drugs were derived from natural sources such as plants and microorganisms is evidence for their ability to cure several types of diseases such as prostate, breast, lung, and colon cancers. In addition, the anti-cancer activities of numerous natural products are presently being studied to identify potential anti-cancer agents which could improve the efficacy of specific targeted remedies against cancer [9-13]. Most new clinical applications of plant secondary metabolites and their derivatives over the last half century have been applied toward battling cancer $[14,15]$.

The National Cancer Institute collected about 35,000 plant samples from 20 countries and has studied around 114,000 extracts for anti-cancer activity [16]. Over 3000 species of plants with anti-tumor properties have been reported [17]. The genus Clerodendrum (Verbenaceae, more recently placed in the Lamiaceae) is a diverse genus with 580 species [18] of small trees, shrubs, or occasionally perennial herbs, typically in the tropical and subtropical region around the world [19]. A number of species from this genus have been used in traditional systems of medicine by several tribes in many countries like China, Japan, India, Korea, and Thailand [20]. This genus has been found to contain terpenoids as the major secondary metabolites $[21,22]$. The genus also contain neo clerodane diterpenes [23], triterpenes [24], and iridoids [25]. Phenolic compounds have been frequently reported with phenyl propanoids and flavonoids as a principal class $[26,27]$ and few of species have been reported to have macro cyclic alkaloids and cyanogenic glycosides [28, 29]. Some of these compounds have been assessed for a number of activities mostly antiinflammatory [30, 31], anti-asthmatic [32, 33], hepatoprotective [34], antioxidant [35], cytotoxicity [36], anti-tumor [37], and for the effects on central nervous system [38].

Clerodendrum thomsoniae Balf.f. is a twining, rambling, vine-like shrub native to tropical West Africa. Bleeding-heart vine or Bag-flower is the collective name of Clerodendrum thomsoniae Balf.f [19, 39]. The leaves and flowers of Clerodendrum thomsoniae Balf.f. are the main bases of several medicinally significant phytocompounds. These phytocompounds protect the human body from oxidative stress by their own capable defense mechanism and curing diseases like bruises, cuts, skin rashes, and sores [40]. The objective of the study was to evaluate in vitro cytotoxic activity of Clerodendrum thomsoniae Balf.f. and its active fractions on different cancer and normal cell lines.

\section{Methods \\ Plant material}

Aerial parts of Clerodendrum thomsoniae Balf.f. were obtained locally from Calicut District (Kerala, India). The plant materials were identified and authenticated by the Botany Department, Calicut University (Calicut, India). Voucher specimens were deposited in the same department herbarium as specimen no. 148249.

\section{Preparation of extracts}

The aerial parts of Clerodendrum thomsoniae Balf.f. were dried properly in shade for 3 weeks, segregated, pulverized by a mechanical grinder, and passed through a 40 mesh sieve. About $1 \mathrm{~kg}$ of air-dried plant material was extracted in soxhlet assembly successively with petroleum ether, chloroform, ethyl acetate, ethanol and water (order of increasing polarity). Each time before extracting with the next solvent, the powdered material was dried at room temperature. Each extract was concentrated by using a rotary vacuum evaporator. The extract obtained with each solvent was weighed and the percentage yield was calculated in terms of the dried weight of the plant material. The color and consistency of the extract were also noted. All the solvents used for this entire work were of analytical grade (Merck, Mumbai).

\section{Phytochemical analysis}

Phytochemical tests were carried out using standard procedures to identify constituents, as described by Harborne [41], Trease and Evans [42], and kokate [43].

\section{Tests for alkaloids}

One milliliter of extracts and Dragondroff's reagents were mixed in a test tube. The precipitation of orangered color indicates the presence of alkaloids in the extract. The addition of Wagner's reagent to the extract produces reddish-brown residue also represents alkaloids. Similarly, the formation of white precipitate on Mayer's reagent addition to the extract indicates alkaloid presence. The appearance of yellow precipitate on Hager's reagent addition also helps to know alkaloids' presence in the extract.

\section{Test for carbohydrates}

One milliliter of $\alpha$-naphthol and $2 \mathrm{ml}$ of extracts were mixed in a test tube. The presence of purple or reddishviolet color at the junction of the two liquids on the addition of concentrated sulphuric acid through the test tube's side slowly indicates the presence of carbohydrate (Molisch Test). Another test was with Fehling's reagent. In this test, equal quantities of Fehling's solution A and 
B were added to $1 \mathrm{ml}$ of the extract. The presence of carbohydrates was indicated by the formation of a red brick precipitate upon heating. According to Benedict's test, $1 \mathrm{ml}$ of extract solution was added to $5 \mathrm{ml}$ of Benedict's reagent and boiled for $2 \mathrm{~min}$ and cooled. The formation of a red precipitate can confirm the presence of carbohydrates.

\section{Tests for proteins and amino acids}

According to Biuret test, add $1 \mathrm{ml}$ of $40 \%$ sodium hydroxide solution to $1 \mathrm{ml}$ of the extract, followed by two drops of $1 \%$ copper sulfate solution. The formation of a violet color will be an indication of the presence of proteins. The presence of amino acids was assessed by Xanthoprotein test. According to this test, $1 \mathrm{ml}$ of concentrated nitric acid was added to $1 \mathrm{ml}$ of the extract that results in the formation of a white precipitate. The obtained white residue is then boiled and cooled. Subsequently, $20 \%$ of sodium hydroxide or ammonia was added. The appearance of orange color is the indication of aromatic amino acids.

\section{Test for steroid}

One milliliter of plant extract, an equal volume of chloroform was added, and the presence of steroids was indicated by the presence brown ring upon the addition of few drops of concentrated sulphuric acid.

\section{Tests of glycosides}

The extract was dissolved in pyridine, and to make it alkaline, sodium nitroprusside solution was added. The presence of glycosides was shown by the formation of the pink-red to red color (Legal test). According to Keller Killiani test, the extract was dissolved into acetic acid with traces of ferric chloride and then transferred a test tube having sulphuric acid. At the junction, glycosides were found to develop a reddish-brown color, gradually become blue.

\section{Test for saponins}

In this test, $2 \mathrm{ml}$ of distilled water was added to $2 \mathrm{ml}$ of plant extract and shaken in a graduated cylinder for 15 min. One centimeter foam layer formation indicates the presence of saponins.

\section{Test for flavonoids}

One milliliter of the extract, magnesium ribbon was added, followed by 1-2 drops of concentrated hydrochloric acid. Formation of the red color showed the presence of flavonoids.

Test for tannins and phenolic compounds

The ferric chloride was added to $1 \mathrm{ml}$ of the extract. The presence of tannins can be confirmed by the formation of a dark blue or greenish-black color. In distilled water, a little extract was dissolved. A few drops of lead acetate solution have been added to this. White precipitate formation indicates the presence of phenolic compounds.

\section{Test for triterpenoids}

Chloroform was added to $5 \mathrm{~mL}$ of the extract together with a few drops of concentrated sulphuric acid. The mixture was shaken and kept for a while. The red color appears in the lower layer indicates the presence of steroids and the yellow color formation in the lower layer indicates the presence of triterpenoids.

\section{Test for quinones}

One milliliter of sulphuric acid was added to $1 \mathrm{ml}$ of extract. Red color formation indicates the presence of quinone in the extract.

\section{Test for anthraquinones}

A few drops of $10 \%$ ammonia solution were added to 1 $\mathrm{ml}$ of plant extract, the formation of pink color precipitate indicates the presence of anthraquinones

\section{Fractionation of ethyl acetate extract}

The ethyl acetate extracts were subjected to column chromatography using silica gel (mesh size 60-120). Fifty grams of the extract was submitted to flash chromatography using silica gel (mesh size 60-120) as the stationary phase. The silica column was prepared using ethyl acetate by wet packing method and the column was washed using $100 \mathrm{ml}$ of ethyl acetate. Then, the ethyl acetate extract was mixed with silica gel and made fine powder for easy distribution of the sample. The powdered sample mass was placed on the top of the pre-packed silica column. The elution was done using increasing solvent polarity made of hexane: ethyl acetate and methanol mixtures. Every $10 \mathrm{ml}$ of fractions were collected in vials and further analyzed by thin layer chromatography. Similar fractions were pooled together to produce seven fractions (F1-F7), evaporated to dryness and kept in the dark for subsequent analysis.

Table 1 Percentage yield and color of various solvent extracts from Clerodendrum thomsoniae Balf

\begin{tabular}{llll}
\hline S. no. & Extracts & Color & Yield \% (W/W) \\
\hline 1. & Petroleum ether & Greenish Yellow & 3.17 \\
2. & Chloroform & Green & 2.86 \\
3. & Ethyl acetate & Brownish Green & 12.58 \\
4. & Ethanol & Brown & 7.24 \\
5. & Water & Chocolate Brown & 9.62 \\
\hline
\end{tabular}


Table 2 Phytochemical analysis of Clerodendrum thomsoniae Balf

\begin{tabular}{|c|c|c|c|c|c|c|}
\hline S. no. & $\begin{array}{l}\text { Phytochemical } \\
\text { constituents }\end{array}$ & Petroleum ether & Chloroform & Ethyl acetate & Ethanol & Water \\
\hline 1. & Alkaloids & - & - & + & + & - \\
\hline 2. & Carbohydrates & - & + & - & + & + \\
\hline 3. & Glycosides & - & - & + & + & + \\
\hline 4. & Terpenoids & - & - & + & - & - \\
\hline 5. & Proteins & - & - & - & - & + \\
\hline 6. & Amino acids & - & - & + & + & + \\
\hline 7. & Steroids & - & - & + & + & + \\
\hline 8. & Flavonoids & - & + & + & + & - \\
\hline 9. & Phenols & - & + & + & - & - \\
\hline 10. & Tannins & - & - & - & - & - \\
\hline 11. & Quinones & - & - & - & - & - \\
\hline 12 & Anthraquinones & - & - & - & - & - \\
\hline 13 & Saponins & - & - & - & - & + \\
\hline
\end{tabular}

Key: + presence, - absence

\section{Cell culture}

MCF-7 (human breast cancer cells), Hep-G2 (human liver cancer cells), A549 (human lung cancer cells), HT29 (human colon cancer cells), MOLT-4 (human acute $\mathrm{T}$ lymphoblastic leukemia cells), Hela cells (human cervical cancer cells), and Vero (African green monkey kidney cells) cell line were cultured separately in liquid medium (DMEM) supplemented 10\% fetal bovine serum (FBS), $100 \mu \mathrm{g} / \mathrm{ml}$ penicillin and $100 \mu \mathrm{g} / \mathrm{ml}$ streptomycin, and maintained under an atmosphere of $5 \% \mathrm{CO}_{2}$ at 37 ${ }^{\circ} \mathrm{C}$. All cell line was purchased from the National Centre for Cell Sciences (Pune, India).

\section{In vitro anti-cancer activity assay by MTT method}

The test sample was evaluated for in vitro cytotoxicity on selected cell lines by 3-(4, 5-dimethylthiazol2-yl)-2, 5-diphenyltetrazolium bromide (MTT) assay. Briefly, the cultured cells were harvested by trypsinization, pooled in a $15 \mathrm{ml}$ tube. Then, the cells were plated at a density of $1 \times 10^{5}$ cells $/ \mathrm{ml}$ cells/well (200 $\mu \mathrm{L}$ ) into 96-well tissue culture plate in DMEM medium containing $10 \%$ FBS and $1 \%$ antibiotic solution for $24-48 \mathrm{~h}$ at $37{ }^{\circ} \mathrm{C}$. The wells were washed with sterile PBS and treated with different concentrations of the test sample in a serum-free DMEM medium. Each sample was replicated three times and the cells were incubated at $37{ }^{\circ} \mathrm{C}$ in a humidified $5 \%$ $\mathrm{CO}_{2}$ incubator for $24 \mathrm{~h}$. After the incubation period, MTT $(20 \mu \mathrm{L}$ of $5 \mathrm{mg} / \mathrm{ml})$ was added into each well and the cells incubated for another 2-4 h until purple precipitates were clearly visible under an inverted microscope. Finally, the medium together with MTT $(220 \mu \mathrm{L})$ were aspirated off the wells and washed with $1 \times$ PBS $(200 \mu \mathrm{l})$. Furthermore, to dissolve formazan crystals, DMSO $(100 \mu \mathrm{L})$ was added and the plate was shaken for $5 \mathrm{~min}$. The absorbance for each well was measured at $570 \mathrm{~nm}$ using a micro plate reader (Thermo Fisher Scientific, USA) and the percentage cell viability and $\mathrm{IC}_{50}$ value was calculated using GraphPad Prism 6.0 software (USA).

\section{Statistical analysis}

All the data expressed as mean \pm SEM were analyzed by one-way analysis of variance (ANOVA), using GraphPad Prism version 6 software.

Table $3 I_{50}$ of different solvent extracts of Clerodendrum thomsoniae Balf on different cell lines

\begin{tabular}{|c|c|c|c|c|c|c|c|}
\hline \multirow[t]{2}{*}{ Extracts } & \multicolumn{7}{|c|}{$\mathrm{IC}_{50}$ value in $\mu \mathrm{g} / \mathrm{ml}$} \\
\hline & Hep-G2 & A549 & MCF-7 & HT-29 & Hela & MOLT-4 & Vero \\
\hline Petroleum ether & $213.12 \pm 2.14$ & $312.43 \pm 1.42$ & $174.43 \pm 3.45$ & $287.21 \pm 3.56$ & $259.22 \pm 2.44$ & $317.11 \pm 1.67$ & $522.45 \pm 2.21$ \\
\hline Chloroform & $112.43 \pm 2.48$ & $213.54 \pm 2.34$ & $256.23 \pm 1.72$ & $157.44 \pm 2.84$ & $312.32 \pm 2.65$ & $247.33 \pm 2.34$ & $425.45 \pm 2.14$ \\
\hline Ethyl acetate & $43.22 \pm 1.02$ & $56.93 \pm 1.41$ & $29.43 \pm 1.44$ & $60.68 \pm 1.05$ & $40.02 \pm 1.14$ & $69.83 \pm 1.33$ & $367.5 \pm 1.03$ \\
\hline Ethanol & $178.23 \pm 1.09$ & $183.87 \pm 2.45$ & $119.22 \pm 3.47$ & $213.11 \pm 2.34$ & $229.12 \pm 2.67$ & $311.24 \pm 3.47$ & $574.29 \pm 2.27$ \\
\hline Water & $389.22 \pm 2.46$ & $299.11 \pm 2.89$ & $234.39 \pm 2.94$ & $253.39 \pm 3.56$ & $211.23 \pm 3.78$ & $159.34 \pm 3.61$ & $>600$ \\
\hline
\end{tabular}

All values are in mean \pm SEM $(n=3)$ 


\section{Results}

\section{Extraction yield}

The percentage yield and color of all five extracts are listed in the following (Table 1). The highest percentage was observed in ethyl acetate extract $(12.58 \% \mathrm{w} / \mathrm{w})$, and the lowest was noted in chloroform extract $(2.86 \% \mathrm{w} / \mathrm{w})$.

\section{Phytochemical analysis}

The phytochemical analysis showed that most of the phytoconstituents are present in ethyl acetate extracts. Detailed reports are listed in the following table (Table 2). The chloroform extract contains flavonoids and phenols to a minor extent. Ethyl acetate extracts showed a high presence of steroids, flavonoids, terpenoids, and phenols.

\section{Evaluation of $\mathrm{IC}_{50}$ using MTT assay}

The $\mathrm{IC}_{50}$ value was determined based on cell viability rates. The results are listed in the following table (Table 3). The morphological profile of the Vero cells after treated with ethyl acetate extract of $C$. thomsoniae is given at Fig. 1. The $\mathrm{IC}_{50}$ values showed that ethyl acetate extracts showing more toxicity on all cancer cell lines used, especially more toxicity selectively to MCF-7 cells $\left(\mathrm{IC}_{50}=29.43 \pm 1.44 \mu \mathrm{g} /\right.$ $\mathrm{ml}$ ). The $\mathrm{IC}_{50}$ observed for ethyl acetate extract on MCF-7 was $43.22 \pm 1.02,56.93 \pm 1.41,60.68 \pm 1.05,40.02 \pm 1.14$, and $69.83 \pm 1.33$ for Hep-G2, A549, HT-29, Hela, and MOLT-4, respectively (all values are in $\mu \mathrm{g} / \mathrm{ml}$ ). The selective cytotoxic activity of ethyl acetate extract may be due to the presence of different phytoconstituents present in this plant and most of them are soluble in ethyl acetate. The morphological profile of the MCF-7 cells after treated with ethyl acetate extract of $C$. thomsoniae is given at Fig. 2.

The results showed Vero cells were not showing toxicity any of the extracts treated which reveals the safety of this plant. Ethyl acetate extracts was selected for fractionation because of its specific toxicity on MCF-7 when compared to other cell lines. $\mathrm{IC}_{50}$ value of ethyl acetate

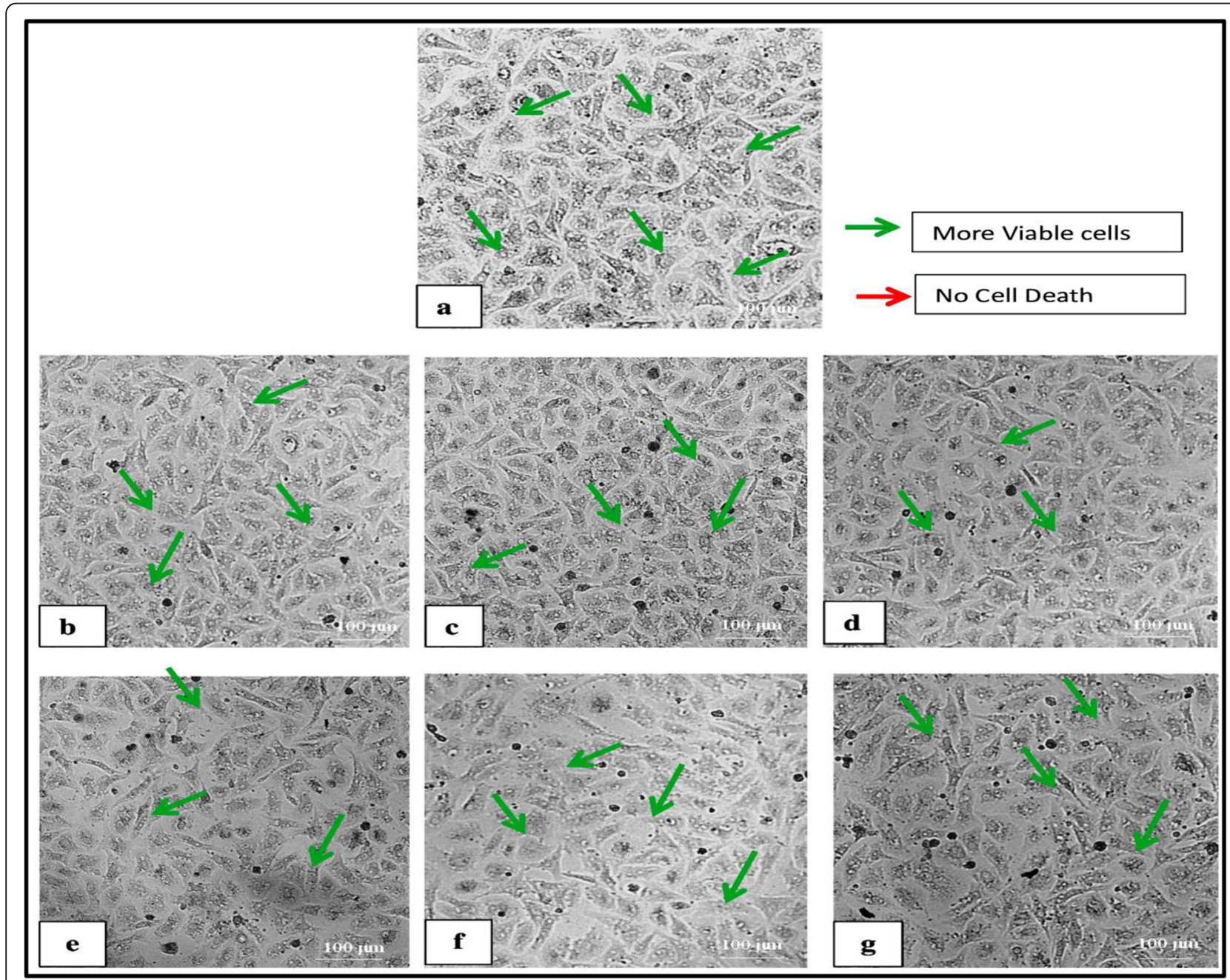

Fig. 1 Morphological profile of the Vero cells after treated with ethyl acetate extract of Clerodendrum thomsoniae Balf $1.0 \mu \mathrm{gg} / \mathrm{mL}$ (b), $10 \mu \mathrm{g} / \mathrm{mL}$ (c) $50 \mu \mathrm{g} / \mathrm{mL}$ (d) $100 \mu \mathrm{g} / \mathrm{mL}(\mathbf{e}), 300 \mu \mathrm{g} / \mathrm{mL}$ (f), and $500 \mu \mathrm{g} / \mathrm{mL}$ (g) compared to control (a) for $24 \mathrm{~h}$ (× 100 enlargement) 


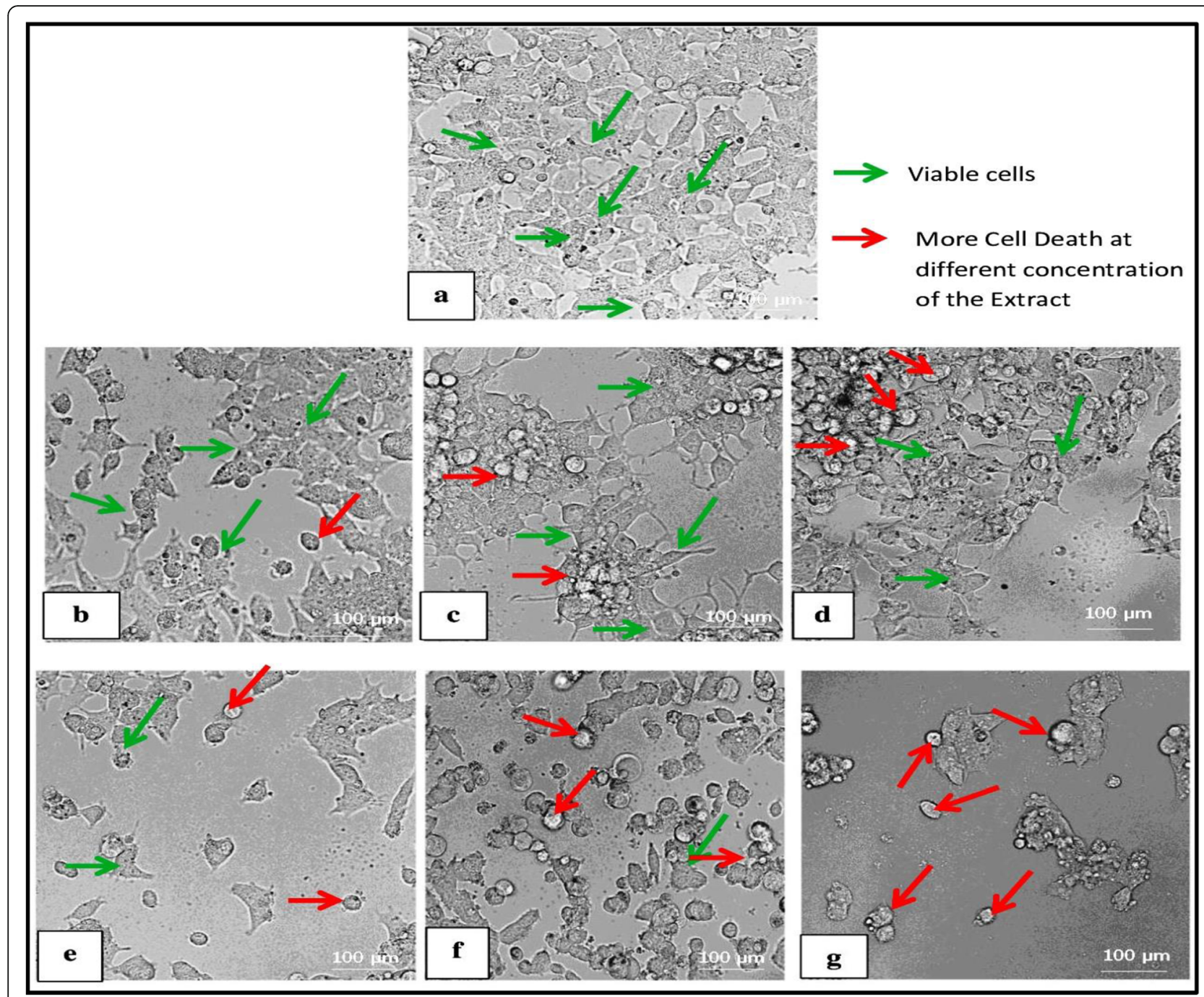

Fig. 2 Morphological profile of the MCF-7 cells after treated with ethyl acetate extract of Clerodendrum thomsoniae Balf.f. at $5.0 \mu \mathrm{g} / \mathrm{mL}$ (b), $10 \mu \mathrm{gg} /$ $\mathrm{mL}(\mathbf{c}), 50 \mu \mathrm{g} / \mathrm{mL}$ (d), $100 \mu \mathrm{g} / \mathrm{mL}(\mathbf{e}), 300 \mu \mathrm{g} / \mathrm{mL}$ (f), and $500 \mu \mathrm{g} / \mathrm{mL}(\mathbf{g})$ compared to control (a) for $24 \mathrm{~h}$ (× 100 enlargement)

extract on MCF-7 was $29.43 \pm 1.44 \mu \mathrm{g} / \mathrm{ml} . \mathrm{IC}_{50}$ value of ethyl acetate extract fractions showed that Fraction F5 was more cytotoxic to MCF-7, then F6, F7, F4, F3, F2, and F1, respectively (Table 4). The morphological profile of the MCF-7 after treated with fraction 5(F5) of ethyl acetate extract of $C$. thomsoniae is given at Fig. 3 .

\section{Discussion}

Cancer is the foremost cause of death worldwide, and as reported by WHO, it caused more deaths than AIDS, tuberculosis, and malaria in 2012. Among the
14 million cancer occurrences in 2012, commonly identified cancers were lung, breast, and colorectal, and the most common causes of cancer death were lung, liver, and stomach cancer (WHO, 2013). The management of cancer relies on surgery, radiotherapy, chemotherapy, or a combination of these methods [43]. Numerous essential anti-tumor drugs have been isolated from plants [44]. Almost one-third of prescribed drugs in the world are derived from plants, and anti-cancer properties of over 3000 plant species have been identified [45].

Table $4 I_{50}$ of fractions of ethyl acetate extract of Clerodendrum thomsoniae Balf on MCF-7

\begin{tabular}{llllllll}
\hline Cell line & MCF-7 & & & & \\
\hline Fractions & F1 & F2 & F3 & F4 & F5 & F6 & F7 \\
$\mathbf{I C}_{\mathbf{5 0}}$ & $85.50 \pm 0.33$ & $48.58 \pm 1.43$ & $44.87 \pm 1.45$ & $26.12 \pm 1.43$ & $17.33 \pm 0.54$ & $19.49 \pm 1.4$ & $26.53 \pm 1.94$
\end{tabular}




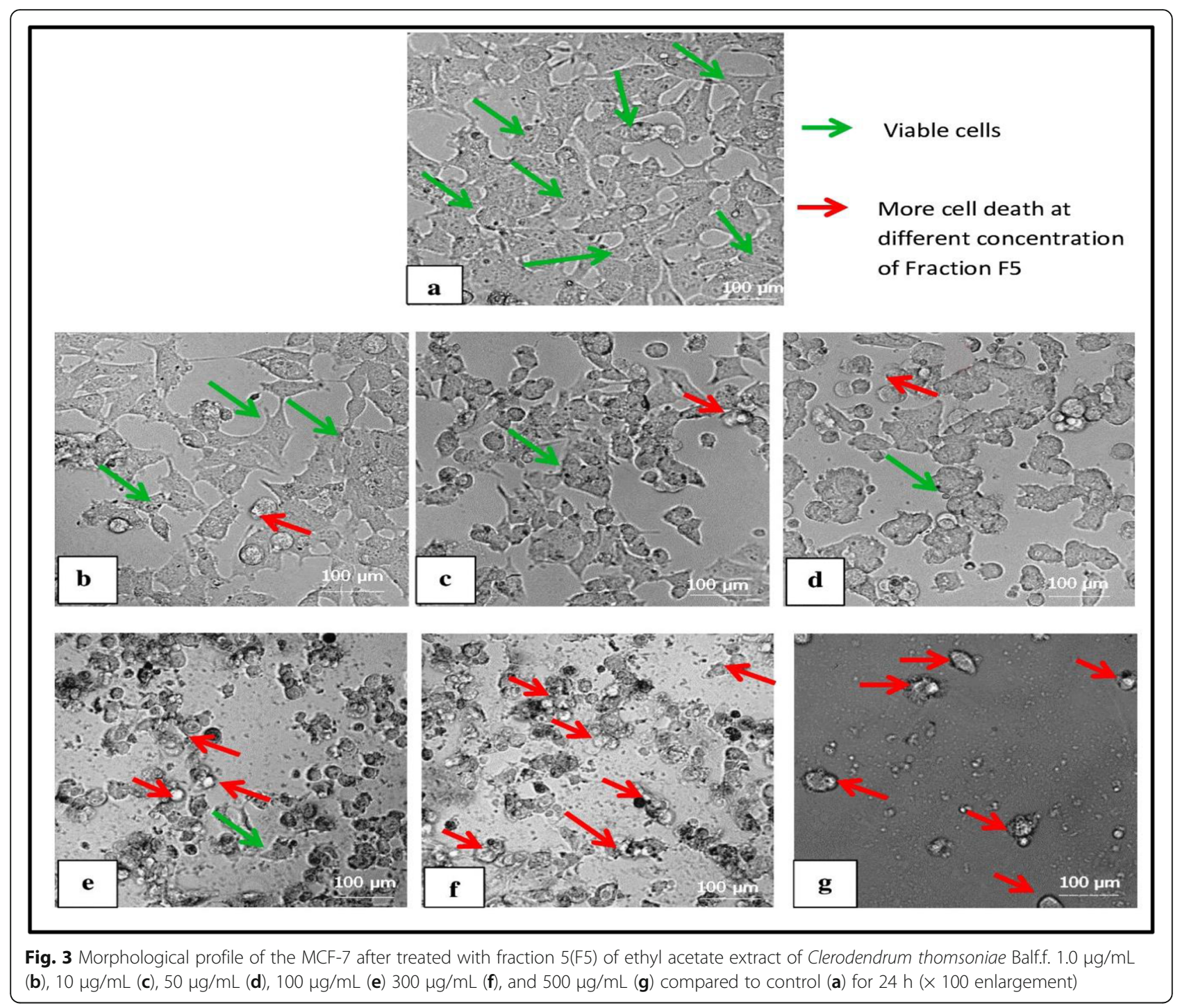

The Clerodendrum genus has been a good source of herbal medicinal products. The pharmacological investigation has shown that these compounds and extracts from the Clerodendrum genus have a wide-range of activities, such as anti-cancer, anti-inflammatory, analgesic, antioxidant, anti-hypertensive, anti-microbial, anti-diarrheal, hepato-protective, hypoglycemic, hypolipidemic, memory enhancing, and neuroprotective activities [46]. Earlier studies on some Clerodendrum species such as Clerodendrum quadriloculare [47], Clerodendrum trichotomum [48], Clerodendrum bungei [49], Clerodendrum trichotomum [50], Cleroodendrum kiangsiense [51], and Clerodendrum serratum [52] have reported for cytotoxic activity against tumor cell lines.

The percentage yield of extracts will be different in plant parts as well as among plant species. It varies with solvent systems too. In the present study, ethyl acetate extract yield was better when compared with other extracts. The plant parts possessed a varied level of secondary metabolites. The phytochemical analysis revealed that most phytoconstituents are present in ethyl acetate extracts such as phenols, flavonoids, steroids, and alkaloids. In this study, ethyl acetate extracts show more cytotoxicity on breast cancer cell line (MCF-7) when compared to the other cell lines. It has been noted that ethyl acetate extract also showing cytotoxicity to other cell lines used in the present study, such as Hep-G2 $\left(\mathrm{IC}_{50}=43.22\right), \mathrm{A} 549\left(\mathrm{IC}_{50}=56.93\right), \mathrm{HT}-29\left(\mathrm{IC}_{50}=60.68\right)$, Hela $\left(\mathrm{IC}_{50}=40.02\right)$, and MOLT-4 $\left(\mathrm{IC}_{50}=69.83\right)$. According to the literature review, several plant extracts and fractions were used for the evaluation of in vitro cytotoxicity studies. The $\mathrm{IC}_{50}$ value of Doxorubicin was reported as $9.5 \pm 1.0 \mu \mathrm{g} / \mathrm{ml}, 13 \pm 1.0 \mu \mathrm{g} / \mathrm{ml}$, and $11 \pm$ $1.0 \mu \mathrm{g} / \mathrm{ml}$ for A-549, HeLa, and HepG2 cell lines, respectively [53]. The $\mathrm{IC}_{50}$ value of Doxorubicin on MCF7 cells was reported as $2.20 \pm 0.30 \mu \mathrm{g} / \mathrm{ml}$ [54]. Because 
of ethyl acetate extract's selective toxicity on these cell lines, we had performed the fractionation of ethyl acetate to find the more active fraction on the MCF-7 cell line. We observed that fraction $\mathrm{F} 5\left(\mathrm{IC}_{50}=17.33 \mu \mathrm{g} / \mathrm{ml}\right)$ is more active when compared to other fractions tested. According to our earlier studies, GC-MS analysis of the fraction F5 showed different compounds present and noted that the major part was identified as some phenolic compound 2,4-bis(1-phenylethyl)-phenol and 2-(1phenylethyl)-phenol [55]. According to the data available, a similar compound 4-Methyl-2, 6-bis (1-phenylethyl) phenol was reported for anti-cancer potential [56]. Another research has reported that similar compound 4Isopropyl-2, 6-bis(1-phenylethyl)phenol from butanol fraction of Cordyceps bassiana for anti-proliferative and apoptosisinducing activities in selected cancer cell lines [57]. It has been reported that phenolic compounds possess biological properties such as anti-apoptosis, anti-aging, anti-carcinogen, antiinflammation, and inhibition of angiogenesis and cell proliferation activities. So the presence of this compound may be responsible for the cytotoxicity observed in our study, and farther experiment is going on in our laboratory to isolate the active compound responsible for the toxicity on the cancer cell line.

\section{Conclusion}

This study concluded that Clerodendrum thomsoniae Balf.f. having significant cytotoxic activity on different cancer cell lines and it is more selective to breast cancer cell lines based on MTT analysis. These findings suggest that C. thomsoniae is a promising source of active compounds against cancer.

\section{Abbreviations}

MTT: 3-(4,5-Dimethylthiazol-2-yl)-2,5-Diphenyltetrazolium Bromide; WHO: World Health Organization; AIDS: Acquired immunodeficiency syndrome; ANOVA: Analysis of variance; DMEM: Dulbecco's modified Eagle's medium; FBS: Fetal bovine serum

\section{Acknowledgements}

We would like to thank all colleagues for their support during the studies. We specially thank Dr. A.K. Pradeep, Assistant Professor-Department of Botany, Calicut University (Calicut, India), for the authentication of the plant.

\section{Authentication of plant material}

The plant materials were identified and authenticated by Dr. A.K. Pradeep, Assistant Professor -Department of Botany, Calicut University (Calicut, India). Voucher specimens were deposited in the same department herbarium as specimen no. 148249.

\section{Authors' contributions}

All authors contributed to the manuscript. MAVK performed the works, VKK and $W$ supervise the works. RR has done data analysis. All the authors read and approved the final manuscript.

\section{Funding}

This research did not receive any grant from funding agencies.

\section{Availability of data and materials}

The data that support the findings of this study are available from the corresponding author, upon request.
Ethics approval and consent to participate

Not applicable

Consent for publication

Not applicable

\section{Competing interests}

The authors declare that they have no competing interests.

\section{Author details}

'Department of Pharmacy, Annamalai University, Chidambaram, Tamil Nadu, India. ${ }^{2}$ Centre for Bioscience and Nano science Research, Coimbatore, Tamil Nadu 641021, India.

Received: 6 March 2020 Accepted: 8 February 2021

Published online: 19 February 2021

\section{References}

1. Abida P, De Britto AJ, Antoney J, Stephan Raj TL (2016) Evaluation of in vitro anticancer activity of Symplocos cochinchinensis (Lour.) S. Moore bark. Int J Herb Med 4:117-119

2. Jemal A, Bray F, Center MM, Ferlay J, Ward E, Forman D (2011) Global cancer statistics. CA Cancer J Clin 61(2):69-90

3. Altobelli E, Lattanzi A (2014) Breast cancer in European Union: an update of screening programmes as of March 2014 (Review). Int J Oncol 45(5):17851792

4. McGuire, S. (2016). World Cancer Report 2014. Geneva, Switzerland: World Health Organization, International Agency for Research on Cancer, WHO Press, 2015. Advances in Nutrition, 7(2), 418-419.

5. Shrivastava SK, Engineer R, Rajadhyaksha S, Dinshaw KA (2005) HIV infection and invasive cervical cancers, treatment with radiation therapy: toxicity and outcome. Radiotherapy Oncol 74(1):31-35

6. Newlon CM, Hu C-CA, Stratton RM, McDaniel AM (2009) Design of a webbased symptom management intervention for cancer patients. Lecture Notes Comput Sci 5619:775-784. https://doi.org/10.1007/978-3-642-028069_90

7. Balunas MJ, Kinghorn AD (2005) Drug discovery from medicinal plants. Life Sci 78(5):431-441

8. Greenwell M, Rahman PKSM (2015) Medicinal plants: their use in anticancer treatment. Int J Pharm Sci Res 6(10):4103-4112

9. Basmadjian C, Zhao Q, Bentouhami E, Djehal A, Nebigil CG, Johnson RA et al (2014) Cancer wars: natural products strike back. Front Chem 2:20

10. Orang-Ojong BB, Munyangaju JE, Wei MS, Lin M, Wei FG, Foukunang C (2013) Impact of natural resources and research on cancer treatment and prevention: A perspective from Cameroon. Mol Clin Oncol 1:610-620

11. Sawadogo WR, Boly R, Cerella C, Teiten MH, Dicato M, Diederich M (2015) A survey of marine natural compounds and their derivatives with anti-cancer activity reported in 2012. Molecules (Basel, Switzerland) 20(4):7097-7142

12. Giddings LA, Newman DJ (n.d.) Microbial natural products: molecular blue prints for anti-tumor drugs. J Ind Microbiol Biotechnol 40:1181-1210

13. Ko JK, Auyeung KK (2014) Identification of functional peptides from natural and synthetic products on their anticancer activities by tumor targeting. Curr Med Chem 21(21):2346-2356

14. Newman DJ, Cragg GM, Snader KM (2000) The influence of natural products upon drug discovery (Antiquity to late 1999). Natural Product Reports 17(3): 215-234

15. Butler MS (2004) The role of natural product chemistry in drug discoveryt. J Nat Products 67(12):2141-2153

16. Shoeb M (2008) Anticancer agents from medicinal plants. Bangladesh J Pharmacol 1(2):35-41

17. Moerman DE (1984) Plants Used against Cancer: A Survey . Jonathan L. Hartwell. Med Anthropol Newsletter 15(4):109-110

18. Munir AA (1989) A taxonomic revision of the genus Clero- dendrum L. (Verbenaceae) in Australia. J Adel Bot Gard 11(2):101-173

19. Hunt DR, Bailey LH, Bailey EZ (1978) Hortus Third. A Concise Dictionary of Plants Cultivated in the United States and Canada. Kew Bulletin 32(4):801

20. Shrivastava N, Patel T (2007) Clerodendrum and heath care: an overview. Med Aromatic Plant Sci Biotechnol 1:142-150

21. Bharitkar YP, Hazra A, Shah S, Saha S, Matoori AK, Mondal NB (2015) New flavonoid glycosides and other chemical constituents from clerodendrum phlomidisleaves: isolation and characterisation. Nat Product Res 29(19): 1850-1856 
22. Akihisa, T., Matsubara, Y., P., G., Thakur, S., \& Tamura, T. Matsumoto T (1989), Sterols of some Clerodendrum species (Verbenaceae):occurrence of the $24 a-$ and $24 \beta$-epimers of 24-ethyl sterols lacking a delta 25-bond (Vol. Steroids53, pp. 625-638). Vol. Steroids53, pp. 625-638.

23. Krishna Kumari GN, Balachandran J, Aravind S, Ganesh MR (2003) Antifeedant and Growth Inhibitory Effects of Someneo-Clerodane Diterpenoids Isolated fromClerodendronSpecies (Verbenaceae) onEarias vitellaandSpodoptera litura. J Agricultural Food Chem 51(6):1555-1559

24. Rangaswami S, Sarangan S (1969) Sapogenins of Clerodendron serratum. Tetrahedron 25(17):3701-3705

25. Jacke G, Rimpler H (1983) Distribution of iridoid glycosides in Clerodendrum species. Phytochemistry 22(8):1729-1734

26. Kim HJ, Woo E-R, Shin C-G, Hwang DJ, Park H, Lee YS (2001) HIV-1 integrase inhibitory phenylpropanoid glycosides from Clerodendron trichotomum. Archives Pharm Res 24(6):618-618

27. Sinha N, Seth K, Pandey V, Dasgupta B, Shah A (1981) Flavonoids from the Flowers of Clerodendron infortunatum. Planta Medica 42(07):296-298

28. Adsersen A, Adsersen H, Brimer L (1988) Cyanogenic constituents in plants from the Galápagos Islands. Biochem Syst Ecol 16(1):65-77

29. Miller RE, McConville MJ, Woodrow IE (2006) Cyanogenic glycosides from the rare Australian endemic rainforest tree Clerodendrum grayi (Lamiaceae). Phytochemistry 67(1):43-51

30. Panthong A, Kanjanapothi D, Taesotikul T, Wongcome T, Reutrakul V (2003) Anti-inflammatory and antipyretic properties of Clerodendrum petasites $\mathrm{S}$. Moore J Ethnopharmacol 85(1):151-156

31. Park MA, Kim HJ (2007) Anti-inflammatory constituents isolated from clerodendron trichotomum tunberg leaves $(\mathrm{CTL})$ inhibits pro-inflammatory gene expression in LPS-stimulated RAW 264.7 macrophages by suppressing NF-kB activation. Arch Pharmacal Res 30(6):755-760

32. Gupta R, Singh HK (2012) Nootropic potential of Alternanthera sessilis and Clerodendrum infortunatum leaves on mice. Asian Pacific Journal of Tropical Disease 2:\$465-\$470

33. Vincent S, Vijay AR, Jeevanantham P, Ragavan S (2012) In-vitro and in-vivo anti-asthmatic activity of Clerodendrum phlomidis Linn. In guinea pigs. Int J Res Rev Pharm Appl Sci 2:15-28

34. Vidya SM, Krishna V, Manjunatha BK, Mankani KL, Ahmed M, Singh SD (2007) Evaluation of hepato protective activity of Clerodendrum serratum L. Ind J Experimental Biol 45:538-542

35. Rajlakshmi D, Banerjee SK, Sood S, Maulik SK (2003) In-vitro and in-vivo antioxidant activity of different extracts of the leaves ofClerodendron colebrookianumWalp in the rat. J Pharm Pharmacol 55(12):1681-1686

36. Yang G-Z, Fan H, Zheng T, Chen Y (2012) Chemical constituents with freeradical-scavenging activities from the stem of Fissistigma polyanthum. Pharmacognosy Magazine 8(30):98

37. Xu R-L, Wang R, Ding L, Shi Y-P (2013) New cytotoxic steroids from the leaves of Clerodendrum trichotomum. Steroids 78(7):711-716

38. Zhu M, Phillipson J, Greengrass P, Bowery N (1996) Chemical and Biological Investigation of the Root Bark ofClerodendrum mandarinorum. Planta Medica 62(05):393-396

39. Schmid R, Riffle RL (1998) The Tropical Look: An Encyclopedia of Dramatic Landscape Plants. Taxon 47(4):985

40. Ra DF, SI M, Crepin J (2004) Medicinal plants of the Guianas. Department of Botany, National Museum of Natural History, Smithsonian Institution, Guyana, Surinam

41. Harborne JB (1984) Methods of Plant Analysis. Phytochemical Methods:1-36

42. Trease GE, Evans WC (1983) Textbook of pharmacognosy, 12th edn. Tindall and Co., London, pp 343-383

43. Kokate CK (1999) Practical Pharmacognosy. Vallabh Parkashan, New Delhi, pp 123-124

44. Hsu S, Singh B, Schuster G (2004) Induction of apoptosis in oral cancer cells: agents and mechanisms for potential therapy and prevention. Oral Oncology 40(5):461-473

45. Wall ME, Wani MC (1996) Camptothecin and taxol: from discovery to clinic. J Ethnopharmacol 51(1-3):239-254

46. Mosaddegh M, Esmaeili S, Naghibi F, Hamzeloo Moghadam M, Haeri A, Pirani A, Moazzeni H (2012) Ethnomedical survey and cytotoxic activity of medicinal plant extracts used in Kohgiluyeh and Boyerahmad Province in Iran. J Herbs Spices Med Plants 18(3):211-221

47. Wang J-H, Luan F, He X-D, Wang Y, Li M-X (2018) Traditional uses and pharmacological properties of Clerodendrum phytochemicals. J Trad Complementary Med 8(1):24-38
48. Macabeo APG, Villafranca MCG, Aguinaldo AM, Hussain H, Krohn K (2008) Clerosterols from Clerodendrum quadriloculare. Biochem Syst Ecol 36(8): 659-660

49. Wang W-X, Zhu J-J, Zou Y, Hong Z-L, Liu S-T, Li M et al (2013) Trichotomone, a new cytotoxic dimeric abietane-derived diterpene from Clerodendrum trichotomum. Tetrahedron Letters 54(20):2549-2552

50. Wang W-X, Xiong J, Tang Y, Zhu J-J, Li M, Zhao Y et al (2013) Rearranged abietane diterpenoids from the roots of Clerodendrum trichotomum and their cytotoxicities against human tumor cells. Phytochemistry 89:89-95

51. Xu M, Wang S, Jia O, Zhu Q, Shi L (2016) Bioactive Diterpenoids from Clerodendrum kiangsiense. Molecules 21(1):86

52. Zalke AS, Kulkarni AV, Shirode DS, Duraiswamy B (2010) In-vivo anticancer activity of Clerodendrum serratum (L) Moon. Res J Pharm Biol Chem Sci 1(89)

53. Lalitha L, Sales T, Clarance PP, Agastian P, Kim Y, Mahmoud A, Kim H (2020) In-vitro phytopharmacological and anticancer activity of Loranthus Longiflorus Desv. Var. Falcatuskurz against the human lung cancer cells. J King Saud Univ Sci 32(1):1246-1253

54. Chaudhary S, Chandrashekar KS, Pai KSR, Setty MM, Devkar RA, Reddy ND, Shoja MH (2015) Evaluation of antioxidant and anticancer activity of extract and fractions of Nardostachys jatamansi DC in breast carcinoma. BMC Complementary Alternative Med 15(1):50

55. Ashraf MVK, Kalaichelvan VK, Ragunathan R, Venkatachalam W (2021) Antiproliferative potential of ethyl acetate extract of Clerodendrum thomsoniae Balf.f. on DMBA-induced breast cancer in female Sprague Dawley rats. Indian J of Pharmaceutical Educ Res 55(1):1-10

56. Sung NY, Kim SC, Kim YH, Kim G, Lee Y, Sung G-H et al (2016) Antiproliferative and pro-apoptotic activities of 4-Methyl-2,6-bis(1phenylethyl)phenol in cancer cells. Biomolecules Therapeutics 24(4):402-409

57. Kim JH, Lee $Y$, Sung G-H, Kim HG, Jeong D, Park JG et al (2015) Antiproliferative and apoptosis-inducing activities of 4-Isopropyl-2,6-bis(1phenylethyl)phenol isolated from butanol fraction ofCordyceps bassiana. Evidence Based Complement Altern Med 2015:1-10

\section{Publisher's Note}

Springer Nature remains neutral with regard to jurisdictional claims in published maps and institutional affiliations.

\section{Submit your manuscript to a SpringerOpen ${ }^{\circ}$ journal and benefit from:}

- Convenient online submission

- Rigorous peer review

- Open access: articles freely available online

High visibility within the field

- Retaining the copyright to your article

Submit your next manuscript at $>$ springeropen.com 